\title{
ПИТАННЯ ПІДВИЩЕННЯ ЕКСПЛУАТАЦЙНОЇ НАДІЙНОСТІ ТЯГОВИХ ЕЛЕКТРОДВИГУНІВ ЕЛЕКТРИЧНОГО ТРАНСПОРТУ
}

\section{Шавкун В. М.}

\section{ВСТУП}

Удосконалення транспортного обслуговування населення пов'язано з ефективною роботою міського електричного транспорту. Це залежить від здатностей та якості окремих вузлів та агрегатів рухомого складу. Крім того, важливу роль відіграють системи електропостачання та керування рухом.

Важливим техніко-економічним показником якості для кожної технічної системи електричного транспорту або виробу $є$ поняття надійності, яке характеризує рівень експлуатаційних умов основних елементів і характеристик тягових електричних двигунів (далі - ТЕД).

Одним з основних критеріїв надійності тягових електродвигунів $\epsilon$ безвідмовність роботи в процесі експлуатації.

Досвід експлуатації рухомого складу міського електротранспорту показує, що значна кількість його відмов відбувається через технічні пошкодження електрообладнання, в яких доля відмов від тягових електричних двигунів складає близько 20\%. Це призводить до припинення функціонування рухомого складу, а також до порушення графіків руху, погіршення якості обслуговування пасажирів. Сукупність відмов у роботі таких електричних машин призводить до значних матеріальних втрат на підприємствах електротранспорту ${ }^{1}$.

Надійність та економічність роботи тягових електричних двигунів та електропривода в цілому визначається рядом факторів ${ }^{2}$ :

- технічним станом рухомого складу;

- рівнем підготовки персоналу електротранспортного підприємства (водіїв, ремонтників та інших);

- кліматичними умовами тощо.

${ }^{1}$ Яцун М.А., Яцун А.М. Експлуатація та діагностування електричних машин і апаратів. Львів : «Львівська політехніка», 2010. 228 с.

2 Технічна експлуатація міського електричного транспорту : навчальний посібник / В.Х. Далека, В.Б. Будниченко, Е.І. Карпушин, В.І. Коваленко. Харків : ХНУМГ, 2014. 235 с. 
Таким чином, наслідки відмов у роботі рухомого складу підвищують актуальність такого напрямку. Це сприяє необхідності розробки подальших технічних рішень і відповідних заходів на науковій основі.

Отже, підвищення експлуатаційної надійності тягових електродвигунів рухомого складу електричного транспорту, організація контролю параметрів у процесі експлуатації є актуальною задачею.

Під час роботи тягового електродвигуна відбуваються різноманітні фізичні процеси, які призводять, в кінцевому підсумку, до таких негативних наслідків ${ }^{3}$ :

- деградації параметрів щодо ряду елементів ТЕД;

- втрати працездатності тягового електродвигуна;

- наявності напруги на корпусі ТЕД, небезпечної для пасажирів і персоналу;

- зростання зношування окремих елементів ТЕД;

- підвищення вібрацій ТЕД із негативним впливом на комфортабельність поїздки й безвідмовність роботи інших елементів рухомого складу.

Крім того, відомо, що основна частина відмов через підвищену вібрацію та попереджувальні технічні впливи припадає на колекторнощітковий вузол ТЕД, а також на підшипники, ізоляцію обмоток якоря та полюсів.

Поява таких небажаних наслідків призводить до демонтажу тягових електродвигунів, що задає матеріальних витрат транспортному підприємству.

Таким чином, забезпечення надійності тягових електродвигунів із подоланням негативних наслідків $\epsilon$ актуальною проблемою. У сучасному світі схожі проблеми розв'язуються ефективними досягненнями досліджень. Це сприяє підвищенню показників надійності ТЕД і рухомого складу в цілому.

У напрямках досліджень параметрів електродвигунів використовуються різноманітні методи, за допомогою яких відбувається діагностування деяких параметрів і характеристик ${ }^{4}$. Так, наприклад, у роботі ${ }^{5}$ зображено метод оцінки електричних параметрів двигунів $\mathrm{i}$ потоку ротора. Цей метод заснований на підході моделі еталонної

3 Шавкун В.М. До питання підвищення надійності тягових електричних двигунів та ресурсозбереження на рухомому складі міського електричного транспорту. Комунальне господарство міст. Серія «Технічні науки і архітектура». ХНАМГ : науково-технічний збірник. 2010. Вип. 97. С. 272-278.

${ }^{4}$ Шавкун В.М. Діагностування тягових електричних машин електротранспорту. Восточно-европейский журнал передовых технологий. 2014. Вып. 1/7 (67). С. 48-52.

${ }^{5}$ Castaldi P., Tilli A. Parameters estimation of induction motor at standstill with magnetic flux monitoring. URL: https://ieeexplore.ieee.org/document/1424016. 
адаптивної системи й може використовуватися тільки для асинхронних двигунів. Специфіка роботи тягових двигунів і зміна їхніх параметрів у реальному часі не дозволяє використовувати цей метод досліджень.

Але в умовах експлуатації тягового електродвигуна практично неможливо зафіксувати параметри відмов деталей i вузлів. Пояснюється це тим, що режим навантаження та параметри міцності елементів змінюються в часі. Тому задача фіксації режимів і параметрів під час навантаження в момент відмов практично не здійснена.

Крім того, в процесі експлуатації ТЕД на його елементи впливають зовнішні й внутрішні чинники, які приводять до росту інтенсивності зношування деталей i вузлів, що змінює характеристики ТЕД i довговічність його елементів. Тому важливим етапом $\epsilon$ встановлення впливу фізичних факторів і закономірностей фізики відмов.

Постійність характеристик ТЕД визначається умовами експлуатації. Крім того, елементна база ТЕД має значну кількість різного роду конструктивних з'єднань між деталями, що утворюють вузли, якість яких визначається умовами й технологією виготовлення. Тому необхідно використовувати інші шляхи з урахуванням вказаних вимог.

Також треба мати на увазі, що ТЕД рухомого складу експлуатуються в різних умовах, внаслідок чого відомі методи досліджень дають неоднозначну оцінку параметрам відмов, яка має систематичну похибку.

Під час випробувань та оцінки елементів ТЕД на надійність виключаються 3 розгляду не пошкоджені деталі й вузли. Це також вносить систематичну похибку в результати досліджень.

Таким чином, аналіз літературних джерел показав, що розглядаються загальні питання 3 дослідження характеристик електричних машин, параметрів надійності й працездатності тягових електричних двигунів. Але до цього часу не досить вивчені й потребують детальнішого дослідження питання зв'язків систем діагностування рухомого складу й обробки інформації.

Тому виникає необхідність пошуку нових шляхів підвищення надійності елементів ТЕД в експлуатації та удосконалення методів досліджень 3 урахуванням фізичних факторів, системи керування технічним станом рухомого складу, зовнішніх і внутрішніх впливів тощо. Така необхідність повинна грунтуватись на врахуванні структурно-функціональних властивостей, а також зв'язків між елементами ТЕД і на особливостях кожної рухомої одиниці під час навантаження під час експлуатації.

Метою роботи є вдосконалення системи діагностування експлуатаційних параметрів тягових електричних двигунів рухомого складу електричного транспорту в процесі експлуатації. Розв'язання 
цього питання дасть змогу підвищити експлуатаційну надійність тягових електричних двигунів.

Для досягнення мети поставлені такі завдання:

- виконати аналіз умов експлуатації тягових електродвигунів, оцінити надійність і визначити шляхи підвищення;

- встановити закономірності зміни параметрів елементів тягових електродвигунів у процесі експлуатації;

- розробити математичну модель оцінки надійності елементів тягових електродвигунів та отримати результати розрахунку необхідних параметрів.

\section{1. Методи дослідження показників надійності елементів тягових електричних двигунів у процесі експлуатації}

Розв'язання наукової задачі базується на процедурі контролю технічного стану параметрів тягових електродвигунів у процесі експлуатації. На цім використовуються методи ${ }^{6}$ :

- статистики й теорії імовірності для аналізу експлуатаційних характеристик тягових електродвигунів;

- математичного моделювання для розробки математичних моделей оцінки надійності елементів тягових електродвигунів.

Такі методи досліджень передбачають збір та аналіз статистичної інформації про відмови тягових електродвигунів, подальшу обробку 3 метою отримання адекватних моделей надійності.

Поетапне дослідження параметрів тягових електродвигунів показало, що математичне очікування та середньоквадратичне відхилення елементів тягових електродвигунів (наприклад, пластин колектора й електрощіток) у функції його пробігу змінюються практично лінійно.

Для кількісної оцінки характеристик надійності елементів тягових електродвигунів з урахуванням статистичних даних використовуються такі основні показники в межах заданого наробітку $l$ :

- імовірність $P(l)$ безвідмовної роботи тягових електродвигунів;

- параметр потоку відмов $\omega(l)$;

- інтенсивність відмов $\lambda(l)$;

- середній наробіток часу до відмов $T_{\mathrm{cp}}$.

Вихідні параметри для досліджень і розрахунку показників надійності елементів тягових електродвигунів є статистичними даними, що приведені в табл. 1.

${ }^{6}$ Бондаренко В.Г., Канівська І.Ю., Парамонова С.М. Теорія імовірностей і математична статистика. Київ : НТТУ «КПІ», 2006. 125 с. 
Статистична інформація, що наведена в табл. $1,-$ це частка технікоекономічних показників роботи комунального підприємства «Тролейбусне депо № 3» м. Харкова (Україна), яка зібрана за 10 років у період з 2010 по 2019 роки.

Таблиця 1

\section{Вихідні дані для розрахунку надійності елементів} тягових електродвигунів

\begin{tabular}{|c|c|c|c|c|c|}
\hline № & $\begin{array}{c}\text { Інвентарна } \\
\text { кількість } \\
\text { рухомого } \\
\text { складу } \\
N_{i}, \text { од. }\end{array}$ & $\begin{array}{c}\text { Коефіцієнт } \\
\text { використання } \\
\text { рухомого } \\
\text { складу по } \\
\text { випуску } \\
\alpha_{b}, \%\end{array}$ & $\begin{array}{c}\text { Експлуатаційна } \\
\text { швидкість } \\
\text { рухомого } \\
\text { складу } \\
V_{e}, \kappa M / 2 о д .\end{array}$ & $\begin{array}{c}\text { Середньодобове } \\
\text { перебування } \\
\text { рухомого складу } \\
\text { на маршруті } \\
t_{c ə}, \text { год. }\end{array}$ & $\begin{array}{c}\text { Кількість } \\
\text { відмов } \\
\text { тягових } \\
\text { електро- } \\
\text { двигунів } \\
m_{\text {TЕд }}\end{array}$ \\
\hline 1 & 151 & 0,687 & 15,21 & 10,04 & 42 \\
\hline 2 & 148 & 0,647 & 15,19 & 10,05 & 62 \\
\hline 3 & 129 & 0,549 & 15,23 & 10,06 & 73 \\
\hline 4 & 123 & 0,667 & 15,17 & 10,1 & 69 \\
\hline 5 & 115 & 0,632 & 15,24 & 10,4 & 70 \\
\hline 6 & 108 & 0,681 & 15,25 & 10,5 & 88 \\
\hline 7 & 155 & 0,674 & 15,15 & 10,2 & 78 \\
\hline 8 & 147 & 0,548 & 15,34 & 10,1 & 59 \\
\hline 9 & 144 & 0,569 & 15,08 & 9,8 & 47 \\
\hline 10 & 129 & 0,539 & 15,06 & 9,7 & 32 \\
\hline
\end{tabular}

Ця інформація є достатньою для кількісної оцінки надійності елементів тягових електродвигунів.

\section{2. Результати дослідження показників надійності елементів тягових електричних двигунів у процесі експлуатації}

Надійність $є$ комплексною властивістю, що, залежно від призначення об'єкта й умов його застосування, може містити: безвідмовність (імовірність безвідмовної роботи, середній наробіток до відмови, параметр потоку відмов, інтенсивність відмов), довговічність (середній ресурс), ремонтопридатність (імовірність відновлення працездатного стану, середній час відновлення працездатного стану), збережуваність (середній термін збережуваності) або певні поєднання цих властивостей.

Показники надійності розділяють на дві групи, які характеризують не відновлювані (обмотка ротора й статора, щітки й підшипники) й 
відновлювані (колекторно-щітковий вузол, пускорегулювальна апаратура) об'єкти. Кількісними характеристиками для не відновлюваних об'єктів є ймовірність безвідмовної роботи, частота відмов, інтенсивність відмов, середній наробіток до першої відмови. До кількісних характеристик відновлюваних об'єктів відносять параметр потоку відмов і наробіток на відмову.

На відміну від електродвигунів загального призначення, тягові електродвигуни працюють у самих різноманітних режимах (короткочасні, повторно-короткочасні 3 частими пусками), які супроводжуються широкою зміною частоти обертання ротора й навантаженням по струму (наприклад, під час рушання з місця може у 2 рази перебільшувати номінальний), а також не захищені від зміни погодних умов.

У зв'язку із цим виникає необхідність розробки й впровадження в технологічні процеси ремонту різних методів, методик, технологій i засобів діагностування. Вони спрямовані на підвищення надійності тягових електродвигунів і збільшення ресурсу. У табл. 2 наведено фактичні показники надійності тягових електродвигунів міського електротранспорту.

Розрахунки показників надійності елементів тягових електродвигунів проводились на прикладі електричних машин типу ДК-210.

За статистичними даними 3 урахуванням кількості відмов імовірність $P(l)$ :

$$
P(l)=\frac{N-r(l)}{N}=1-\frac{r(l)}{N},
$$

де $N$ - кількість тягових електродвигунів в оцінюваній сукупності; $r(l)$ - кількість початкових відмов до моменту наробітку $l$.

Параметр потоку відмов $\omega(l)$ використовується для характеристики зміни безвідмовності тягових електродвигунів i визначається відношенням кількості всіх відмов об'єктів розглянутої сукупності $\Delta l$ до кількості об'єктів в оцінюваній сукупності й величини інтервалу наробітку:

$$
\omega(l)=\frac{\Delta r_{i}}{N \cdot \Delta l},\left[\frac{1}{\mathrm{KM}}\right]
$$

де $\Delta r_{i}-$ кількість відмов у розглянутому інтервалі наробітку.

Інтенсивність відмов $\lambda(l)$ характеризує надійність елементів у кожен момент часу й визначається: 


$$
\lambda(l)=\frac{\Delta r_{i}}{N \cdot \Delta l} \cdot \frac{1}{P_{i}}
$$

де $P_{i}-$ імовірність безвідмовної роботи $i$-го тягового електродвигуна.

Середній наробіток часу безвідмовної роботи $T_{\mathrm{cp}}$ - це математичне очікування часу справної роботи ТЕД і визначається як:

$$
T_{c p}=\frac{\sum_{i=1}^{N} l_{i}}{N},
$$

де $l_{i}$ - наробіток справної роботи $i$-го тягового електродвигуна.

Результати статистичної оцінки експлуатаційної надійності наведено в табл. 2.

Таблиця 2

\section{Результати статистичної оцінки експлуатаційної надійності}

\begin{tabular}{|c|c|c|c|c|c|c|}
\hline$№$ & $\begin{array}{c}\text { Величина } \\
\text { інтервалу } \\
\text { напрацю- } \\
\text { вання } \\
\Delta l \times 10^{3}, \text { км }\end{array}$ & $\begin{array}{c}\text { Кількість } \\
\text { відмов } \\
\text { в інтервалі } \\
\Delta r_{i}\end{array}$ & $\begin{array}{c}\text { Кількість } \\
\text { відмов } \\
\text { наростальн } \\
\text { им } \\
\text { підсумком } \\
\Sigma \Delta r_{i}\end{array}$ & $\begin{array}{c}\text { Імовірність } \\
\text { безвідмовн } \\
\text { ої роботи } \\
P(l)\end{array}$ & $\begin{array}{c}\text { Параметр } \\
\text { потоку } \\
\text { відмов } \\
\omega(l) \times 10^{-6}\end{array}$ & $\begin{array}{c}\text { Інтенсив- } \\
\text { ність } \\
\text { відмов } \\
\lambda(l) \times 10^{-6}\end{array}$ \\
\hline 1 & $0-35$ & 136 & 136 & 0,815 & 5,286 & 5,286 \\
\hline 2 & $35-70$ & 89 & 225 & 0,694 & 3,459 & 4,245 \\
\hline 3 & $70-105$ & 103 & 328 & 0,554 & 4,004 & 5,770 \\
\hline 4 & $105-140$ & 95 & 423 & 0,424 & 3,693 & 6,669 \\
\hline 5 & $140-175$ & 64 & 487 & 0,337 & 2,488 & 5,860 \\
\hline 6 & $175-210$ & 70 & 557 & 0,242 & 2,721 & 8,064 \\
\hline 7 & $210-245$ & 60 & 617 & 0,160 & 2,332 & 9,630 \\
\hline 8 & $245-280$ & 44 & 661 & 0,100 & 1,710 & 10,65 \\
\hline 9 & $280-315$ & 28 & 689 & 0,062 & 1,088 & 10,81 \\
\hline 10 & $315-350$ & 20 & 712 & 0,031 & 8,941 & 14,28 \\
\hline
\end{tabular}

Результати досліджень параметрів ТЕД, які минули стадію ремонту в залежності від пробігу, показані у вигляді гістограми на рис. 1.

Аналіз гістограми показує, що 20\% ТЕД, які вийшли 3 ладу, припадає на перший період роботи - напрацювання. Це вказує на недосконалі технології елементів або на низьку якість ремонту й недосконалість методів попередніх випробувань ТЕД на нагрів. Такі 
випробування визначають зміну основних параметрів ТЕД під час виникнення короткого замикання та, як наслідок, підвищення струму, що впливає на якість ізоляції обмоток якоря під час інтенсивного нагріву. Залежність імовірності безвідмовної роботи ТЕД та інтенсивності відмов показано на рис. 2 і на рис. 3 .

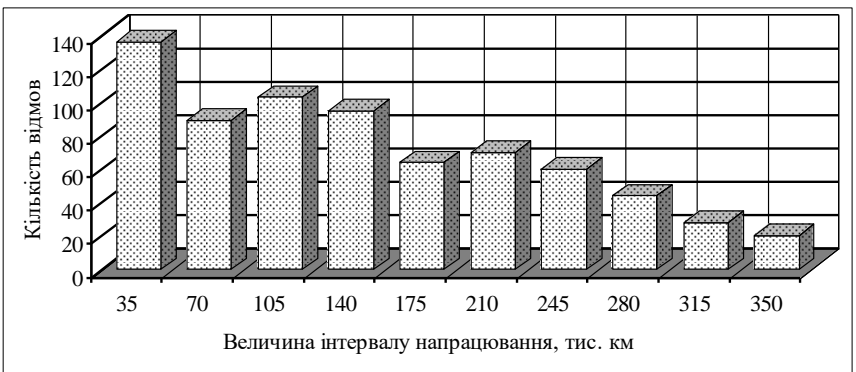

Рис. 1. Гістограма кількості відмов $\Delta r_{i}$ тягових електродвигунів у залежності від інтервалу напрацювання $\Delta l$

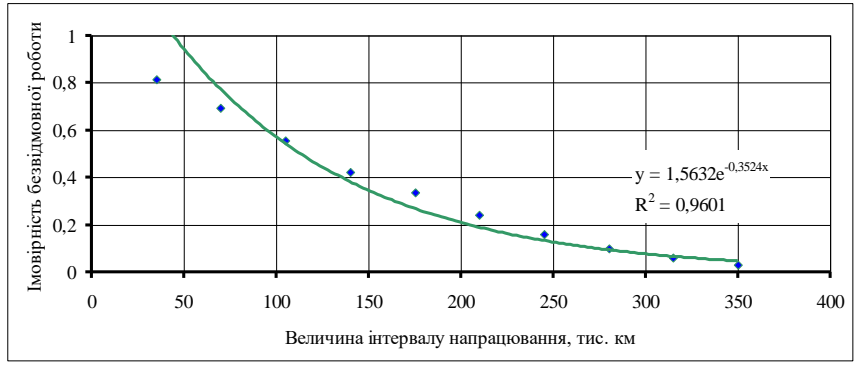

Рис. 2. Графік імовірності безвідмовної роботи $P(l)$ тягових електродвигунів у залежності від інтервалу напрацювання $\Delta l$

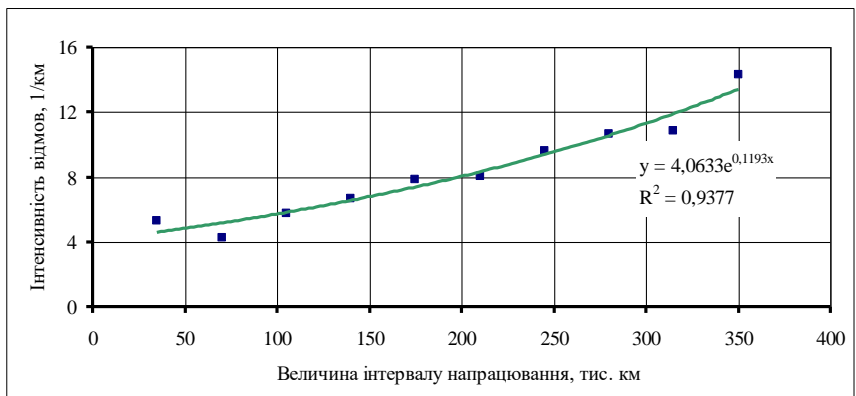

Рис. 3. Графік інтенсивності відмов $\lambda(l)$ тягових електродвигунів у залежності від інтервалу напрацювання $\Delta l$ 
Відомо, що після ремонту відновляється ресурс елементів ТЕД і збільшується надійність роботи, яка залежить від якості ремонту й умов післяремонтної експлуатації. Але іноді умови експлуатації ТЕД не відповідають заданим технічним вимогам та, як правило, практично не корегуються після ремонту останніх, що призводить до збільшення інтенсивності відмов.

Численні дослідження показали, що поліпшення якості післяремонтних випробувань $є$ одним зі шляхів підвищення надійності ТЕД. Підвищенням якості випробувань ТЕД у такому випадку $є$ збільшення точності й достатнього обсягу інформації про дослідницький об’єкт шляхом застосування методів оцінки параметрів надійності. Це підвищить надійність роботи ТЕД, зменшить енерго- й ресурсовитрати, що пов'язані з відмовами й ремонтом.

3 урахуванням вказаних факторів, використовуються фізикостатистичні методи. Вони засновані на інформації фізики процесів під час експлуатації ТЕД і на статистичних даних про відмови.

Крім того, в деяких випадках використовуються аналітичні методи визначення надійності технічних систем, які мають складні внутрішні структури й функціональні зв'язки. Це дозволяє створювати необхідні методи моделювання, які передбачають припущення, а також знімають обмеження та прийняті умови.

Наприклад, строк служби електричної частини двигуна в залежності від температури визначається, в основному, старінням ізоляції:

$$
t_{x}=t_{0}^{-\beta \Delta \tau},
$$

де $t_{0}$ - строк служби при номінальній температурі для заданого класу ізоляції; $\Delta \tau$ - параметри, що характеризують заданий клас ізоляції; $\beta$ - перевищення гранично допустимої температури.

Водночас визначається параметр інтенсивності раптових i параметричних відмов. Але застосування виразу (5) не дозволяє врахувати конструктивної особливості ТЕД рухомого складу й нерівномірність нагріву частин елементів ТЕД. Це призводить до збільшення похибок, які можуть досягти значних величин.

3 урахуванням багатьох вимог розроблена математична модель оцінки надійності з використанням комбінованих методів розрахунку.

Відсутність імовірнісно-статистичних даних по характеру відмов з'єднань елементів ускладнює оцінку параметрів надійності системи в цілому.

У технічних умовах на виготовлення та експлуатацію передбачається необхідність дотримання встановлених геометричних параметрів між вузлами й деталями. Відхилення цих параметрів істотно 
впливає на комутацію, роботу магнітної системи, підшипникових вузлів, ізоляцію та призводить до тяжких видів відмов, що вимагають заводського ремонту.

Усі перераховані умови вимагають ретельного дослідження, тому що недотримання та відсутність законів формування викликає тяжкі види відмов в експлуатації транспорту ${ }^{7}$.

Аналіз статистичних даних відмов показує, що природа виникнення відмов і наслідків залежить від складності структури, функціональних зв'язків параметрів тягових електродвигунів і різноманіття впливу експлуатаційних факторів. Тому обмежимося постулатами основних законів густини розподілу параметрів надійності елементів, що входять у структурну схему, та їх оцінкою.

На цій основі можна сформувати банк даних, які будуть характеризувати ймовірнісно-статистичні властивості елементів системи. Таким чином, маючи густину розподілу відмов елементів та оцінки, шляхом варіювання параметрами моделі, отриманої на базі структурної схеми, можна визначати раціональні рівні параметрів надійності для системи.

Через наявний розкид параметрів навантаження та міцності елементів імовірність безвідмовної роботи деталі тягового електродвигуна можна виразити такою залежністю:

$$
\begin{aligned}
& p(t)=\lambda \int_{0}^{\infty} e^{-\lambda t} \mathrm{~d} t\left[1-\frac{1}{\sigma \sqrt{2 \pi}} \int_{0}^{\infty} e^{-\frac{(t-m)^{2}}{2 \sigma^{2}}} \mathrm{~d} t\right] \times \\
& \times \frac{1}{\sqrt{2 \pi \sigma}} \int_{0}^{\infty} \frac{e^{-\frac{(t-m)^{2}}{2 \sigma^{2}}}}{\int_{0}^{t_{2}} e^{t_{2}-\frac{U^{2}}{2}} \mathrm{~d} U-\int_{0}^{t_{1}} e^{t_{1}-\frac{U^{2}}{2}} \mathrm{~d} U},
\end{aligned}
$$

де $m, \sigma, \lambda$ - статистичні параметри, що характеризують властивості елемента й умови його експлуатації; $t, t_{1}, t_{2}-$ час напрацювання деталей тягового електродвигуна.

Інша група елементів виражається експоненціальним і нормальним законами розподілу:

$$
p(t)=\lambda \int_{0}^{\infty} e^{-\lambda t} \mathrm{~d} t \frac{1}{\sigma \sqrt{2 \pi}} \int_{0}^{\infty} e^{-\frac{(t-m)^{2}}{2 \sigma^{2}}} \mathrm{~d} t .
$$

7 Шавкун В.М., Щацький С.П. Вплив періодичності діагностування на показники надійності тягових електродвигунів рухомого складу електротранспорту. Комунальне господарство міст. Серія «Технічні науки і архітектура». ХНАМГ : науково-технічний збірник. 2011. Вип. 101. С. 265-269. 
Поєднання нормального й усічено-нормального законів розподілу представлено як:

$$
p(t)=\left[1-\frac{1}{(\sigma 2 \pi)^{2}} \int_{0}^{\infty} e^{-\frac{(t-m)^{2}}{2 \sigma^{2}}} \mathrm{~d} t\right] \int_{0}^{\infty} \frac{e^{-\frac{\left(t-t_{0}\right)^{2}}{2 \sigma^{2}}}}{\int_{0}^{4} e^{-\frac{U^{2}}{2}}-\int_{0}^{4} e^{-\frac{U^{2}}{2}} \mathrm{~d} U},,
$$

Можливе також поєднання параметрів елементів, що мають експоненціальну й усічено-нормальну густину розподілу. Тоді ймовірність безвідмовної роботи:

$$
p(t)=\frac{1}{\sigma 2 \pi} \lambda \int_{0}^{\infty} e^{-\lambda t} \mathrm{~d} t \int_{0}^{\infty} \frac{e^{-\frac{\left(t-t_{0}\right)^{2}}{2 \sigma^{2}}}}{\int_{0}^{\tau} e^{-\frac{U^{2}}{2}} \mathrm{~d} t-\int_{0}^{\tau} e^{-\frac{U^{2}}{2}} \mathrm{~d} t} .
$$

Маючи такі аналітичні залежності, можна шляхом перебору варіантів встановити найраціональніші співвідношення, які відповідають необхідним вимогам.

У зв'язку із цим виникає завдання глибшого вивчення ймовірнісностатистичних властивостей відмов елементів системи, на підставі яких можливо буде отримати оцінки надійності системи під час раціонального підбору параметрів надійності елементів.

Статистична інформація про відмови елементів системи накопичується в процесі роботи тягового електродвигуна. На підставі даних експлуатаційних спостережень за роботою елементів системи й характеру навантаження можна прийняти, що ймовірність безвідмовної роботи, в загальному випадку, буде дорівнювати добутку двох функцій. Таку умову прийнято, виходячи 3 незалежності раптових відмов. Тоді для $k$-го елемента загальна ймовірність безвідмовної роботи:

$$
P_{k}(t)=\left(1-\frac{1}{\sqrt{2 \pi \sigma_{k}}} \int_{0}^{t} \exp \left\{-\frac{\left(x-m_{k}\right)^{2}}{2 \sigma_{k}^{2}}\right\} \mathrm{d} x\right) \exp \left(\lambda_{k}, t\right),
$$

де $m_{k}, \sigma_{k}, \lambda_{k}-$ змінні параметри; $x$ - напрацювання.

Імовірність безвідмовної роботи $є$ функцією декількох змінних $m_{k}$ , $\sigma_{k}, \lambda_{k}$, які $\epsilon$ статистичними параметрами й характеризують властивості елемента й умови його експлуатації.

Різні варіації $m_{k}, \sigma_{k}$ і $\lambda_{k}$ відносно нуля та одне одного змінюють імовірнісно-статистичні характеристики відмов тягового електродвигуна.

Аналіз властивостей $m_{k}, \sigma_{k}$ і $\lambda_{k}$ показує, що вони є випадковими величинами, розподіленими на деяких інтервалах. Це припущення про 280 
випадковість параметрів має очевидний характер, оскільки елементи й реальні умови експлуатації відрізняються один від одного.

Припустимо, що випадкова величина $\xi m_{k}$ розподілена на відрізку $\left[m_{k}^{\prime} ; m_{k}^{\prime \prime}\right]$. Випадкова величина $\xi \sigma_{k}$ розподілена на відрізку $\left[\sigma_{k}^{\prime} ; \sigma_{k}^{\prime \prime}\right]$ й випадкова величина $\xi \lambda_{k}$ на відрізку $\left[\lambda_{k}^{\prime} ; \lambda_{k}^{\prime \prime}\right]$.

На цім випадкові величини $\xi m_{k}, \xi \sigma_{k}, \xi \lambda_{k}$ мають нормальну функцію розподілення 3 математичним очікуванням для $\xi m_{k} \rightarrow m_{k}$; $\xi \sigma_{k} \rightarrow \sigma_{k} ; \quad \xi \lambda_{k} \rightarrow \lambda_{k} ;$ однієї дисперсії $\sigma$.

Випливає задача визначення імовірності $P_{x}$ безвідмовної роботи тягового електродвигуна під час випадкової статистичної зміни ймовірнісних характеристик.

Припустимо, що $P_{x}=P_{k}\left(t, m_{k}, \sigma_{k}, \lambda_{k}\right)$ - значення ймовірності безвідмовної роботи $k$-го елемента при заданому $t$ i при значенні надійності параметрів $\left(m_{k}, \sigma_{k}, \lambda_{k}\right)$, що дорівнює математичному очікуванню випадкових величин $\xi m_{k}, \xi \sigma_{k}, \xi \lambda_{k}$. Тоді для прийнятих умов незалежності відмов надійність вузла або машини в цілому дорівнює добутку ймовірності безвідмовної роботи елементів. Приймемо $t$ фіксованим, а параметри $\left(m_{k}, \sigma_{k}, \lambda_{k}\right)$ змінними, значення яких знаходяться в інтервалах:

$$
\xi m_{n} \in\left[m_{k}^{\prime} ; m_{k}^{\prime \prime}\right] ; \quad \xi \sigma_{n} \in\left[\sigma_{k}^{\prime} ; \sigma_{k}^{\prime \prime}\right],
$$

Якщо $P^{\xi m}$ - значення функції ймовірності безвідмовної роботи елемента при $m_{k}$, рівному $\xi m$, та інших статистичних параметрах, рівних математичним очікуванням, то приймаємо такі ж умови для $P_{k}^{\xi \sigma}$ i $P_{k}^{\lambda \sigma}$.

Величини часткового впливу елементів на систему в залежності від рівнів параметрів характеристик надійності:

$$
\Delta m=P_{k}^{\xi m}-P_{k} ; \Delta \sigma=P_{k}^{\xi \sigma}-P_{k} ; \Delta \lambda=P_{k}^{\xi \lambda}-P_{k} .
$$

Введемо нову функцію, яка залежить від статистичних параметрів:

$$
\Delta P=\frac{\sqrt{\Delta m^{2}+\Delta \sigma^{2}+\Delta \lambda^{2}}}{P}
$$

яка характеризує відносну зміну імовірності безвідмовної роботи системи $\Delta P$ при абсолютній зміні статистичних параметрів $\left(m_{k}, \sigma_{k}, \lambda_{k}\right)$. Функція $\Delta P$ задана в просторі $3 n$ - вимірювань, де $n$ - кількість елементів системи Значення цієї функції завжди більше нуля. 
При заданні частини області $\varepsilon>0$ для функції $\Delta P(t)$ виконується умова $0<\Delta P(t)<\varepsilon$. У такому випадку виникає обернена задача знаходження тієї частини області завдання функції, де зміна випадкових величин $\xi m_{k}, \xi \sigma_{k}, \xi \lambda_{k}$ не приведе до більшої відносної зміни функції ймовірності безвідмовної роботи системи. При зміні $t$ має змінюватися область допустимих значень $\xi m_{k}, \xi \sigma_{k}, \xi \lambda_{k}$, якщо $\Delta P(t)<\varepsilon$.

Рішення як прямої, так і зворотної задачі в явному аналітичному вигляді неможливо через велику кількість елементів тягового електродвигуна й складних статистичних залежностей параметрів від умов експлуатації. Але похідні рішення для конкретних значень $\varepsilon, t, m_{k}$, $\sigma_{k}, \lambda_{k}$ можливо отримати з використанням комп'ютерних програм.

Під час занесення до банку даних отримуються значення параметрів $m_{k}, \sigma_{k}, \lambda_{k}$, а також межі значень $\left[m_{k}^{\prime} ; m_{k}^{\prime \prime}\right],\left[\sigma_{k}^{\prime} ; \sigma_{k}^{\prime \prime}\right],\left[\lambda_{k}^{\prime} ; \lambda_{k}^{\prime \prime}\right]$, закони їх зміни й розрахункові формули. Генератор випадкових чисел у заданій області формує значення для $\xi m_{k}, \xi \sigma_{k}, \xi \lambda_{k}$ і в підсумку обчислюється за формулами $P(t)$ і $\Delta P(t)$ при деяких фіксованих $t$ (наприклад, при $t$, рівному ресурсу машини).

На рис. 4 приведені графічні залежності, що характеризують надійність елементів 3 урахуванням часових $\mathrm{i}$ кількісних характеристик.

Оцінки параметрів для різних законів щільності густини розподілення дозволяють визначити кількісні характеристики раптових і параметричних відмов зносу деталей електродвигуна.

Як порівняння з результатами статистичної оцінки експлуатаційної надійності (табл. 2 і рис. 2, 3) нижче наведені графічні залежності надійності деталей тягових електродвигунів (рис. 5, 6), які побудовані на підставі даних експлуатації, методів діагностики й прогнозування.

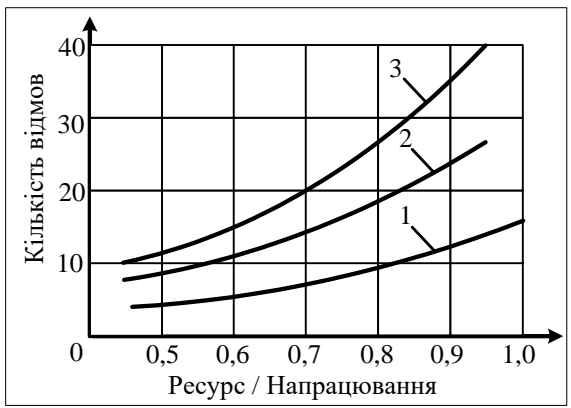

Рис. 4. Залежність кількості відмов (m) від параметрів ресурсу і напрацювання $(m / N)$ елементів: $1,2,3$ - криві, що відповідають вимогам:

$$
\frac{t}{T}<1 ; \frac{t}{T}=1 ; \frac{t}{T}>1 ; \text { відповідно }
$$




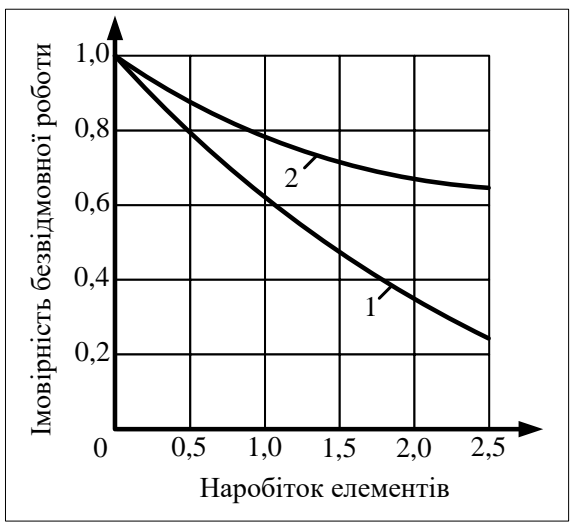

Рис. 5. Залежність імовірності безвідмовної роботи $P(t)$ щіткотримача тягового електродвигуна в залежності від наробітку $\left(l \times 10^{6}\right.$, км):

1, 2 - елементи двополюсної системи

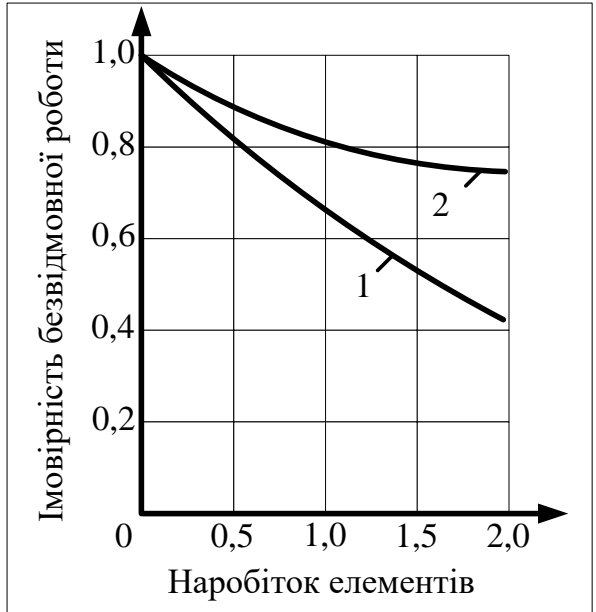

Рис. 6. Залежність імовірності безвідмовної роботи $\boldsymbol{P}(\boldsymbol{t})$ колектора тягового електродвигуна в залежності від наробітку $\left(l \times 10^{6}\right.$, км): 1,2 - елементи двополюсної системи

Як показали дослідження, ресурс деталей тягового електродвигуна значно відрізняється один від одного. У результаті частка деталей, для яких він перевищує встановлений наробіток до відновлення чи заміни, має на заданому інтервалі практично мало відмов та, як наслідок, залежить від закону розподілення. Якщо вважати, що закон розподілення відмов і його параметри відомі $N\{t ; T ; \sigma\}$, і задано 
наробіток на ремонт або відновлення деталі, то імовірність, що деталь напрацює більше заданого значення, буде дорівнювати:

$$
P\{\xi>t\}=\int_{t}^{t+\infty} f(x) \mathrm{d} x
$$

де $f(x)$ - густина розподілення.

Таким чином, на підставі теоретичних положень та аналізу ймовірнісно-статистичних характеристик елементів системи формується банк даних. Його поповнення сприятиме реалізації завдання отримання оцінок надійності тягових електричних двигунів i забезпечення безвідмовності в експлуатації. Надалі таке рішення відкриває можливості розвитку автоматизованого процесу діагностування.

\section{3. Обробка результатів теоретичних та експериментальних досліджень оцінки параметрів тягових електродвигунів у процесі експлуатації}

На основі оновлених структурно-функціональних схем тягового електричного двигуна, що враховують зв'язки між іншими елементами й підсистемами, отримано їх моделі ${ }^{8}$. Вони дають змогу аналітично описати надійність всього електродвигуна як електротехнічної функціональної системи й отримати математичну модель (14) імовірності його відмов у цілому.

Отримані моделі підсистем елементів тягових електричних двигунів дають можливість аналітично описати надійність будь-якої системи. На підставі раніше прийнятих припущень, відмова будь-якої з підсистем спричиняс відмову тягових електродвигунів i, після відповідних перетворень, можна отримати також модель імовірності відмови для будь-якої системи:

$$
Q(E)=Q\left\{E^{(i)}(T)\right\}+\sum_{i=2}^{5} \prod_{i=1}^{i=1}\left[1-Q\left\{E^{(i)}(T)\right\}\right] Q\left\{E^{(j)}(T)\right\},
$$

де $Q\left\{E^{(i)}(T)\right\}$ - імовірність відмови $j$-ої підсистеми $[2,12,17]$.

Кількість відмов в інтервалі $0-t$ при більших значеннях імовірності $Q$ значно зменшується. При певних значеннях можна вважати потік відмов у такому інтервалі стаціонарним, що задовольняє вимогам Пуассонівського потоку. Тоді модель імовірності відмов в інтервалі $0-t$ можна отримати, якщо підставити в (13) вираз для $f(x)$, і після інтегрування лівої та правої сторони отримаємо:

8 Далека В.Х., Шавкун В.М. Вплив параметрів технічного стану тягових електродвигунів на безпеку перевезення пасажирів. Комунальне господарство міст. Серія «Технічні науки і архітектура». ХНАМГ : науково-технічний збірник. 2013. Вип. 104. С. 432-435. 


$$
P\{\xi>t\}=\left\{\begin{array}{ll}
1-\exp [-\lambda t], & t>0, \\
0, & t=0 .
\end{array},\right.
$$

Якщо вираз не враховує кількість елементів системи, то можна використовувати метод визначення кількості відмов, де враховується загальна кількість елементів $N$, які знаходяться в експлуатації.

Водночас елементи мають задовольняти іншим таким вимогам.

Припустимо, що $m$ - кількість відмов за час $T_{c p}$ для $N$ справних ідентичних елементів. Тоді:

$$
\ln \left(1-\frac{m}{N}\right)=-\lambda T_{c p},
$$

У виразі (16) ліва частина знаходиться емпіричним шляхом. Логарифмуючи вираз (16), отримаємо:

$$
\ln \left(1-\frac{m}{N}\right)=-\lambda T_{c p},
$$

3 виразу (17) знаходимо інтенсивність відмов $\lambda$ :

$$
\lambda=-\frac{1}{T_{c p}} \ln \left(1-\frac{m}{N}\right),
$$

Тоді, підставляючи (18) в (15), отримаємо:

$$
P\{\xi>t\}=1-\exp \left[-\frac{1}{T_{c p}} \ln \left(1-\frac{m}{N}\right) t\right],
$$

Якщо $m$ - кількість відмов за час $t$ для $N$ справних елементів:

$$
\frac{m}{N}=1-\exp \left[-\frac{1}{T_{c p}} \ln \left(1-\frac{m}{N}\right) t\right],
$$

Після перетворення маємо:

$$
m=N\left\{1-\exp \left[-\frac{1}{T_{c p}} \ln \left(1-\frac{m}{N}\right) t\right],\right.
$$

Таким чином, визначення механізмів отримання параметрів надійності роботи тягового електродвигуна залежить від умов його роботи й кількості відмов елементів, що знаходяться в експлуатації. Тому використовують різноманітні методи, які сприятимуть підвищенню експлуатаційних характеристик тягових електродвигунів і надійності роботи під час експлуатації. Сукупність позитивних умов відбиває надійність роботи рухомого складу в цілому. 


\section{ВИСНОВКИ}

За результатами обробки статистичної інформації підприємств електротранспорту й аналізу умов експлуатації систем та агрегатів рухомого складу виявлено, що електричне обладнання має динаміку зростання відмов. Встановлено, що відмови тягових двигунів складають $20 \%$ від усіх відмов електрообладнання. Проаналізовано умови експлуатації тягових електричних двигунів, проведено оцінку надійності.

Дослідження ймовірнісно-статистичних характеристик функцій густини розподілу відмов тягових електродвигунів показує, що деякі відмови апроксимуються асиметричним розподілом. У зв'язку із цим доцільно застосовувати усічено-нормальну функцію розподілу $N\{t ; \quad T ; \quad \sigma\}, \quad$ яка дозволить підвищити адекватність моделей. Встановлено, що при великих значеннях імовірності $Q$ значно зменшується число відмов в інтервалі $0-t_{1}$, для певних значень якого можна вважати потік відмов у цьому інтервалі стаціонарним.

На основі структурно-функціональних схем елементів тягових електродвигунів розроблено математичну модель оцінки надійності (14), яка, на відміну від наявних моделей, базується на системному аналізі ймовірностей відмов підсистем, що підлягають діагностуванню (щіткоутримуючого вузла, статора, якоря, колектора). Вона дозволяє визначати параметри різних елементів тягових електродвигунів впродовж експлуатації. Модель якісно відрізняється від наявних тим, що враховує конструктивні й електромагнітні характеристики й дозволяє оптимізувати параметри різних вузлів відносно до вимог системи планово-попереджувального ремонту, коли тягові двигуни виробили заданий ресурс і продовжують експлуатуватися.

За результатами досліджень і наведених розрахунків можливо оцінити параметри надійності будь-якого типу тягового електродвигуна.

\section{АНОТАЦІЯ}

Тягові електродвигуни, що використовуються на міському електричному транспорті, забезпечують ефективність роботи електропривода, тому надійність визначає працездатність рухомого складу в цілому. Проаналізовано умови експлуатації тягових електродвигунів, проведено оцінку надійності й визначено шляхи іiі підвищення. Встановлено закономірності зміни параметрів елементів тягових електродвигунів у процесі експлуатації. Розроблено математичну модель оцінки надійності елементів тягових електродвигунів. 


\section{ЛITЕРАТУРА}

1. Яцун М.А., Яцун А.М. Експлуатація та діагностування електричних машин і апаратів. Львів : «Львівська політехніка», 2010. $228 \mathrm{c}$.

2. Технічна експлуатація міського електричного транспорту : навчальний посібник / В.Х. Далека, В.Б. Будниченко, Е.І. Карпушин, В.І. Коваленко. Харків : ХНУМГ, 2014. 235 с.

3. Шавкун В.М. До питання підвищення надійності тягових електричних двигунів та ресурсозбереження на рухомому складі міського електричного транспорту. Комунальне господарство міст. Серія «Технічні науки $i$ архітектура». ХНАМГ : науково-технічний збірник. 2010. Вип. 97. С. 272-278.

4. Шавкун В.М. Діагностування тягових електричних машин електротранспорту. Восточно-европейский журнал передовых технологий. 2014. Вып. 1/7 (67). С. 48-52.

5. Castaldi P., Tilli A. Parameters estimation of induction motor at standstill with magnetic flux monitoring. URL: https://ieeexplore.ieee.org/ document/1424016.

6. Бондаренко В.Г., Канівська І.Ю., Парамонова С.М. Теорія імовірностей і математична статистика. Київ : НТТУ «КПІ», 2006. 125 с.

7. Шавкун В.М., Щацький С.П. Вплив періодичності діагностування на показники надійності тягових електродвигунів рухомого складу електротранспорту. Комунальне господарство міст. Серія «Технічні науки $i$ архітектура». ХНАМГ : науково-технічний збірник. 2011. Вип. 101. С. 265-269.

8. Далека В.Х., Шавкун В.М. Вплив параметрів технічного стану тягових електродвигунів на безпеку перевезення пасажирів. Комунальне господарство міст. Серія «Технічні науки і архітектура».

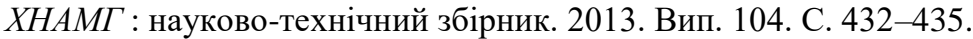

\section{Information about author:} Shavkun V. M.,

Candidate of Technical Sciences, Associate Professor, Associate Professor at the Department of Electric transport of O. M. Beketov National University of Urban Economy in Kharkiv 17, Marshala Bazhanova str., Kharkiv, 61002, Ukraine 